
Not for reproduction, distribution or commercial use.

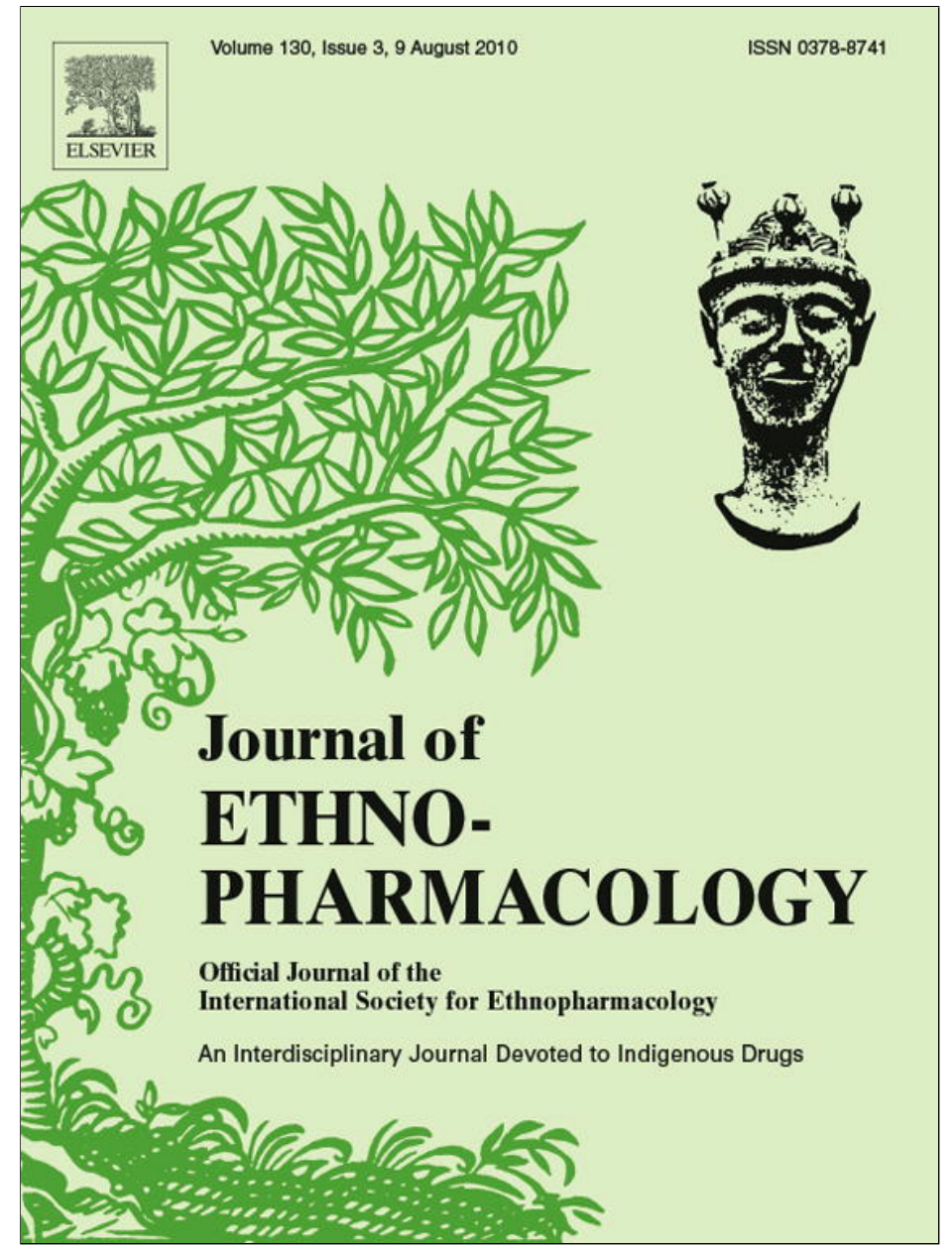

This article appeared in a journal published by Elsevier. The attached copy is furnished to the author for internal non-commercial research and education use, including for instruction at the authors institution and sharing with colleagues.

Other uses, including reproduction and distribution, or selling or licensing copies, or posting to personal, institutional or third party websites are prohibited.

In most cases authors are permitted to post their version of the article (e.g. in Word or Tex form) to their personal website or institutional repository. Authors requiring further information regarding Elsevier's archiving and manuscript policies are encouraged to visit: 


\title{
Essential oils from Distichoselinum tenuifolium: Chemical composition, cytotoxicity, antifungal and anti-inflammatory properties
}

\author{
Ana Cristina Tavares ${ }^{\mathrm{a}}$, Maria José Gonçalves ${ }^{\mathrm{b}}$, Maria Teresa $\mathrm{Cruz}^{\mathrm{c}}$, Carlos Cavaleiro ${ }^{\mathrm{b}}$, \\ Maria Celeste Lopes ${ }^{\mathrm{c}}$, Jorge Canhoto ${ }^{\mathrm{a}}$, Lígia Ribeiro Salgueiro ${ }^{\mathrm{b}, *}$ \\ a Centre of Pharmaceutical Studies, Department of Life Sciences, University of Coimbra, Ap. 3046, 3001-401 Coimbra, Portugal \\ ${ }^{\mathrm{b}}$ Laboratório de Farmacognosia, Faculdade de Farmácia/Centre of Pharmaceutical Studies, Pólo das Ciências da Saúde, Azinhaga de Santa Comba, Universidade de Coimbra, 3000-548 \\ Coimbra, Portugal \\ c Faculdade de Farmácia e Centro de Neurociências e Biologia Celular de Coimbra, Universidade de Coimbra, 3000-295 Coimbra, Portugal
}

\section{A R T I C L E I N F O}

\section{Article history:}

Received 26 February 2010

Received in revised form 11 May 2010

Accepted 25 May 2010

Available online 9 June 2010

\section{Keywords:}

Distichoselinum tenuifolium

Essential oil

Myrcene

Antifungal activity

Cytotoxicity

Anti-inflammatory activity

\begin{abstract}
A B S T R A C T
Ethnopharmacological relevance: Several aromatic plants and their essential oils are known to possess antimicrobial and anti-inflammatory properties. Distichoselinum tenuifolium (Lag.) Garcia Martin \& Silvestre, an Iberian endemism, is traditionally used in the treatment of contact dermatitis and skin infections. However, the cellular mechanisms through which this plant exerts their beneficial effects are not known.

Aim of the study: The aims of this study were to examine the chemical composition of the essential oil isolated from Distichoselinum tenuifolium, and to test the efficacy of the essential oil as an antifungal and anti-inflammatory potential.

Materials and methods: The oils were investigated by gas chromatography (GC) and gas chromatography-mass spectrometry (GC-MS) and the antifungal activity (minimal inhibitory concentrations: MIC and minimal lethal concentrations: MLC) were evaluated against yeasts, dermatophyte and Aspergillus strains. Assessment of cell viability was made by the 3-(4,5-dimethylthiazol-2-yl)-2,5diphenyltetrazolium bromide (MTT) assay and the in vitro anti-inflammatory potential of Distichoselinum tenuifolium oil was evaluated by measuring nitric oxide (NO) production induced by LPS, in the absence or in the presence of the oil, in a mouse macrophage cell line.

Results: The oils are predominantly composed of monoterpene hydrocarbons, being myrcene the main compound (47.7-84.6\%). The oils revealed significant antifungal activity against Cryptococcus neoformans and dermatophyte strains and significantly inhibited NO production stimulated by LPS in macrophages, without affecting cell viability at concentrations ranging from $0.64 \mu \mathrm{L} / \mathrm{mL}$ to $1.25 \mu \mathrm{L} / \mathrm{mL}$.

Conclusion: These findings add significant information to the pharmacological activity of Distichoselinum tenuifolium essential oils, specifically to its antifungal and anti-inflammatory properties, thus justifying and reinforcing the use of this plant on traditional medicine. Therefore, their beneficial effects and use in disease prevention, especially those related to fungal infections and inflammation, should be explored in more depth.
\end{abstract}

() 2010 Elsevier Ireland Ltd. All rights reserved.

\section{Introduction}

Natural products provide a significant source of potential drugs from which humankind has identified not only phytomedicines and herbal remedies, but also most of our current antibiotics and anticancer drugs. The medicinal properties of plants from the Apiaceae (Umbelliferae) family are known since immemorial times and nowadays, more than 100 cultivated Apiaceae species are regis-

\footnotetext{
* Corresponding author. Tel.: +351 239 859995; fax: +351239827126

E-mail address: ligia@ff.uc.pt (L.R. Salgueiro).
}

tered for several uses, mainly as medicinal plants (41\%), particularly due to their essential oils (Khoshbakht et al., 2007; Edris, 2007). The potential use of Apiaceae essential oils as antimicrobial (Di Pasqua et al., 2005; Kosalec et al., 2005; Ozcan et al., 2006; Demirci et al., 2007; Tavares et al., 2008; Oroojalian et al., 2010) has been described previously. However, studies concerning the cytotoxicity and anti-inflammatory properties of Apiaceae essential oils are scarce.

In the Iberian Peninsula there are 14 endemic Apiaceae species, most of them widely used as herbal remedies (Ekiert, 2000; Castroviejo, 2003; Küpeli et al., 2006). Continuing the chemical and biological studies on the Iberian endemic Apiaceae 
widely used in traditional medicine in Portugal (Tavares et al., 2008), in this work we report the results obtained with the essential oils of Distichoselinum tenuifolium (Lag.) Garcia Martin Silvestre.

Distichoselinum Garcia Martin \& Silvestre was proposed as a new Apiaceae genus in 1983 (Martin and Silvestre, 1983). In fact, some taxonomic characters from Elaeoselinum tenuifolium (Lag.) Lange were considered to be different from the others species of the genus Elaeoselinum, and a new genus was proposed, being a new combination made: Distichoselinum tenuifolium (Lag.) Garcia Martin \& Silvestre (= Elaeoselinum tenuifolium). In Portugal this species is widespread in the province of Algarve-S Portugal (Castroviejo, 2003) and it is traditionally used in the treatment of contact dermatitis and skin infections (Ronda et al., 1998; Morillas-Sánchez and Fernández-López, 2006).

We provided, for the first time, the antifungal activity of the essential oils of Distichoselinum tenuifolium against yeasts, dermatophyte and Aspergillus strains. Since nitric oxide (NO) produced in large quantities by activated inflammatory cells has been demonstrated to be involved in the pathogenesis of inflammation, being for this reason a well established marker of inflammation (Hofseth, 2008), we also evaluate the effects of Distichoselinum tenuifolium essential oils on NO production triggered by LPS in a mouse macrophage cell line.

\section{Materials and methods}

\subsection{Plant material}

Wild plants were sustainably collected from two different sites in the Algarve province (South Portugal): Moncarapacho and Burgau. Umbels of Distichoselinum tenuifolium were collected during two different vegetative phases: flowering umbels (sample 1: from Moncarapacho and sample 3: from Burgau) and ripe umbels-with mature seeds (sample 2: Moncarapacho and sample 4: from Burgau). After harvesting, the umbels were air-dried in the shade. Plant taxonomy was confirmed and voucher specimens (Moncarapacho COI00005906; Burgau COI00005905) were deposited at the Herbarium of the Department of Botany of the University of Coimbra (COI).

\subsection{Essential oil isolation}

Essential oils were isolated by water distillation for $3 \mathrm{~h}$ from airdried material, using a Clevenger-type apparatus, according to the procedure described in the European Pharmacopoeia (Council of Europe, 1997).

\subsection{Gas chromatography (GC)}

Analytical GC was carried out using a Hewlett Packard 6890 (Agilent Technologies, Palo Alto, CA, USA) gas chromatograph with HP GC ChemStation Rev. A.05.04 data handling system, equipped with a single injector and two flame ionization detectors (FID). A graphpak divider (Agilent Technologies, Part Number 5021-7148) was used for simultaneous sampling in two Supelco (Supelco Inc., Bellefont, PA, USA) fused silica capillary columns with different stationary phases: SPB-1 (polydimethylsiloxane $30 \mathrm{~m} \times 0.20 \mathrm{~mm}$, film thickness $0.20 \mu \mathrm{m}$ ), and SupelcoWax 10 (polyethyleneglycol $30 \mathrm{~m} \times 0.20 \mathrm{~mm}$, film thickness $0.20 \mu \mathrm{m})$. Oven temperature program: $70-220^{\circ} \mathrm{C}\left(3^{\circ} \mathrm{C} / \mathrm{min}\right), 220^{\circ} \mathrm{C}(15 \mathrm{~min})$; injector temperature: $250^{\circ} \mathrm{C}$; carrier gas: helium, adjusted to a linear velocity of $30 \mathrm{~cm} / \mathrm{s}$; splitting ratio: $1: 40$; detectors temperature: $250^{\circ} \mathrm{C}$.

\subsection{Gas chromatography-mass spectrometry (GC-MS)}

Analyses were carried out using a Hewlett Packard 6890 gas chromatograph fitted with a HP1 fused silica column (polydimethylsiloxane $30 \mathrm{~m} \times 0.25 \mathrm{~mm}$, film thickness $0.25 \mu \mathrm{m}$ ), interfaced with an Hewlett Packard mass selective detector 5973 (Agilent Technologies, Palo Alto, CA, USA) operated by HP Enhanced ChemStation software, version A.03.00. GC parameters as above; interface temperature: $250^{\circ} \mathrm{C}$; MS source temperature: $230^{\circ} \mathrm{C}$; MS quadrupole temperature: $150^{\circ} \mathrm{C}$; ionization energy: $70 \mathrm{eV}$; ionization current: $60 \mu \mathrm{A}$; scan range: 35-350 U; scans/s: 4.51 .

\subsection{Qualitative and quantitative analyses}

The identity of the compounds was achieved from their retention indices on SPB- 1 and SupelcoWax-10 columns and from their mass spectra. Retention indices, calculated by linear interpolation relative to retention times of $\mathrm{C}_{8}-\mathrm{C}_{22} n$-alkanes, were compared with those of authentic samples included in our own laboratory database. Acquired mass spectra were compared with corresponding data of components of reference oils and commercial available standards from a home-made library or from the literature data (Adams, 2004; Joulain and Koning, 1998). Relative amount of individual components was calculated based on GC peak areas without FID response factor correction.

\subsection{Antifungal strains}

Antifungal activity of the oil obtained with major yield from ripen umbels collected in Moncarapacho (one of the most important populations from Algarve) was evaluated against yeasts, Aspergillus and dermatophyte strains: two clinical Candida strains isolated from recurrent cases of vulvovaginal candidosis (Candida krusei H9, Candida guillermondii MAT23), three type strains from the American Type Culture Collection (Candida albicans ATCC 10231, Candida tropicalis ATCC 13803, Candida parapsilosis ATCC 90018) and one type strain from the Colección Española de Cultivos Tipo (Cryptococcus neoformans CECT 1078); three dermatophyte clinical strains isolated from nails and skin (Epidermophyton floccosum FF9, Trichophyton mentagrophytes FF7, Microsporum canis FF1) and two type strains from the Colección Española de Cultivos Tipo (Trichophyton rubrum CECT 2794, Microsporum gypseum CECT 2908); and one Aspergillus clinical strain isolated from bronchial secretions (Aspergillus flavus F44) and two type strains from the American Type Culture Collection (Aspergillus niger ATCC 16404, Aspergillus fumigatus ATCC 46645). Antifungal activity of the main compound of the essential oil, myrcene, was also evaluated against the same strains.

The fungal isolates were identified by standard microbiology methods and stored on Sabouraud broth with glycerol at $-70^{\circ} \mathrm{C}$. Prior to antifungal susceptibility testing, each isolate was inoculated on Sabouraud agar to ensure optimal growth characteristics and purity.

\subsection{Antifungal activity}

A macrodilution broth method was used to determine the minimal inhibitory concentrations (MIC) and minimal lethal concentrations (MLC), according to Clinical and Laboratory Standards Institute (CLSI, formerly NCCLS) references documents M27-A3 (CLSI, 2008a), M27-S3 (CLSI, 2008b) and M38- A2 (CLSI, 2008c) for yeasts and filamentous fungi, respectively.

The serial doubling dilution of the essential oil and its major compound was prepared in dimethyl sulfoxide (DMSO), with concentrations ranging from $0.08 \mu \mathrm{L} / \mathrm{mL}$ to $20 \mu \mathrm{L} / \mathrm{mL}$. Final concentration of DMSO never exceeded $2 \%$. Recent cultures of each strain were used to prepare the cell suspension adjusted to 
Table 1

Composition of the essential oils of Distichoselinum tenuifolium ( 1 and 3 flowering umbels; 2 and 4 ripe umbels).

\begin{tabular}{|c|c|c|c|c|c|c|}
\hline \multirow[t]{3}{*}{$\mathrm{RI}^{\mathrm{a}}$} & \multirow[t]{3}{*}{$\mathrm{RI}^{\mathrm{p}}$} & \multirow[t]{3}{*}{ Compounds ${ }^{a}$} & \multicolumn{4}{|c|}{ Percent in samples (\%) } \\
\hline & & & \multicolumn{2}{|c|}{ Moncarapacho } & \multicolumn{2}{|c|}{ Burgau } \\
\hline & & & 1 & 2 & 3 & 4 \\
\hline 921 & 1016 & Tricicleno & $\mathrm{v}$ & $\mathrm{v}$ & $\mathrm{v}$ & $\mathrm{v}$ \\
\hline 922 & 1030 & $\alpha$-Thujene & 0.1 & $\mathrm{v}$ & 0.3 & 0.2 \\
\hline 930 & 1030 & $\alpha$-Pinene & 1.3 & 0.8 & 0.6 & 1.2 \\
\hline 943 & 1073 & Camphene & 0.1 & 0.1 & $\mathrm{v}$ & $\mathrm{v}$ \\
\hline 964 & 1128 & Sabinene & 2.2 & 0.2 & 11.0 & 6.0 \\
\hline 970 & 1118 & $\beta$-Pinene & 0.9 & 0.7 & 0.7 & 1.1 \\
\hline 980 & 1161 & Myrcene & 77.4 & 84.6 & 47.7 & 59.2 \\
\hline 997 & 1171 & $\alpha$-Phellandrene & 0.6 & 0.3 & 0.3 & $\mathrm{v}$ \\
\hline 1010 & 1187 & $\alpha$-Terpinene & 0.4 & 0.1 & 1.1 & $\mathrm{v}$ \\
\hline 1011 & 1275 & p-Cymene & 0.3 & 0.1 & 0.3 & 1.0 \\
\hline 1020 & 1206 & Limonene & 5.6 & 1.5 & 19.9 & 13.6 \\
\hline 1020 & 1215 & $\beta$-Phellandrene & 1.4 & 0.2 & 1.2 & 1.7 \\
\hline 1046 & 1249 & $\gamma$-Terpinene & 0.7 & 0.1 & 2.7 & $\mathrm{v}$ \\
\hline 1050 & 1458 & trans-Sabinene hydrate & $\mathrm{v}$ & $\mathrm{v}$ & 0.2 & $\mathrm{v}$ \\
\hline 1076 & 1288 & Terpinolene & 2.0 & 0.5 & 1.5 & $\mathrm{v}$ \\
\hline 1081 & 1543 & Linalool & 0.3 & 0.1 & $\mathrm{v}$ & 0.2 \\
\hline 1081 & 1542 & cis-Sabinene hydrate & $\mathrm{v}$ & $\mathrm{v}$ & 0.2 & $\mathrm{v}$ \\
\hline 1084 & & Perilene & $\mathrm{v}$ & 0.1 & $\mathrm{v}$ & 1.9 \\
\hline 1145 & 1666 & Criptone & $\mathrm{v}$ & $\mathrm{v}$ & $\mathrm{v}$ & 0.1 \\
\hline 1157 & 1839 & $p$-Cimene-8-ol & $\mathrm{v}$ & $\mathrm{v}$ & $\mathrm{v}$ & 0.3 \\
\hline 1158 & 1597 & Terpinene-4-ol & 0.9 & 0.1 & 4.1 & 1.5 \\
\hline 1169 & 1692 & $\alpha$-Terpineol & $\mathrm{v}$ & $\mathrm{v}$ & 0.2 & $\mathrm{v}$ \\
\hline 1194 & 1824 & trans-Carveol & $\mathrm{v}$ & $\mathrm{v}$ & $\mathrm{v}$ & 0.2 \\
\hline 1203 & 1467 & Fenchyl acetate & 0.1 & 0.2 & $\mathrm{v}$ & $\mathrm{v}$ \\
\hline 1206 & & Thymyl methyl oxyde & $\mathrm{v}$ & 0.1 & $\mathrm{v}$ & 0.5 \\
\hline 1210 & 1724 & Carvone & $\mathrm{v}$ & $\mathrm{v}$ & $\mathrm{v}$ & 0.4 \\
\hline 1328 & 1688 & $\alpha$-Terpinyl acetate & $\mathrm{v}$ & 0.1 & $\mathrm{v}$ & 0.2 \\
\hline 1369 & 1487 & $\alpha$-Copaene & 2.9 & $\mathrm{v}$ & 3.8 & $\mathrm{v}$ \\
\hline 1466 & 1699 & Germacrene D & 0.6 & 0.5 & 0.6 & $\mathrm{v}$ \\
\hline 1508 & 1751 & $\delta$-Cadinene & 0.1 & $\mathrm{v}$ & 0.1 & $\mathrm{v}$ \\
\hline 1542 & & trans-Nerolidol & $\mathrm{v}$ & 0.2 & $\mathrm{v}$ & 0.2 \\
\hline 1618 & 2174 & T- Muurolol & $\mathrm{v}$ & 0.1 & $\mathrm{v}$ & $\mathrm{v}$ \\
\hline 1622 & 2212 & $\beta$-Eudesmol & $\mathrm{v}$ & 0.1 & $\mathrm{v}$ & $\mathrm{v}$ \\
\hline 1630 & 2216 & $\alpha$-Cadinol & $\mathrm{v}$ & 0.2 & 0.2 & $\mathrm{v}$ \\
\hline \multirow[t]{6}{*}{1639} & 2197 & Bulnesol & $\mathrm{v}$ & $\mathrm{v}$ & 0.3 & $\mathrm{v}$ \\
\hline & & Monoterpene hydrocarbons & 93.1 & 89.4 & 87.4 & 86.2 \\
\hline & & Oxygen containing monoterpenes & 1.7 & 0.9 & 5.1 & 3.6 \\
\hline & & Sesquiterpene hydrocarbons & 3.6 & 0.6 & 4.5 & 0.2 \\
\hline & & Oxygen containing sesquiterpenes & 0.2 & 0.6 & 0.7 & 0.4 \\
\hline & & Total identified & 98.6 & 91.5 & 97.7 & 90.4 \\
\hline
\end{tabular}

$t=\operatorname{traces}(\leq 0.05 \%)$. RI $\mathrm{I}^{\mathrm{a}}=$ Retention indices on the SPB-1 column relative to $\mathrm{C}_{8}$ to $\mathrm{C}_{24} n$-alkanes. $\mathrm{RI}^{\mathrm{p}}=$ Retention indices on the SupelcoWax-10 column relative to $\mathrm{C}_{8}$ to $\mathrm{C}_{24}$ $n$-alkanes.

a Compounds listed in order to their elution on the SPB-1 column.

$1-2 \times 10^{3}$ cells per $\mathrm{mL}$ for yeasts and $1-2 \times 10^{4}$ cells per $\mathrm{mL}$ for filamentous fungi. The concentration of cells was confirmed by viable count on Sabouraud agar. The test tubes were incubated aerobically at $35^{\circ} \mathrm{C}$ for $48 \mathrm{~h} / 72 \mathrm{~h}$ (Candida spp. and Aspergillus spp./Cryptococcus neoformans) and at $30^{\circ} \mathrm{C}$ for 7 days (dermatophytes) and MIC were determined. To evaluate MLC, aliquots $(20 \mu \mathrm{L})$ of broth were taken from each negative tube after MIC reading, and cultured in Sabouraud dextrose agar plates. Plates were then incubated for $48 \mathrm{~h}$ at $35^{\circ} \mathrm{C}$ (Candida spp. and Aspergillus spp.), $72 \mathrm{~h}$ for Cryptococcus neoformans and 7 days at $30^{\circ} \mathrm{C}$ (dermatophytes). In addition, two reference antifungal compounds, amphotericin B (Fluka) and fluconazole (Pfizer) were used to control the sensitivity of tested microorganisms. All tests were performed in RPMI medium. For each strain tested, the grow conditions and the sterility of the medium were checked in two control tubes. The innocuity of the DMSO was also checked at the highest tested concentration. All experiments were performed in triplicate and repeated if the results differed.

\subsection{Cell culture and materials}

The fetal calf serum was from Biochrom KG (Berlin, Germany). 3-(4,5-dimethylthiazol-2-yl)-2,5-diphenyltetrazolium bro- mide (MTT), LPS from Escherichia coli (serotype 026:B6), and all the other reagents were from Sigma Chemical Co. The mouse macrophage cell line Raw 264.7 was obtained from ATCC (number TIB-71) and cultured in endotoxin free Iscove's medium supplemented with $10 \%(\mathrm{v} / \mathrm{v})$ fetal calf serum, $3.02 \mathrm{~g} / \mathrm{L}$ sodium bicarbonate, $100 \mu \mathrm{g} / \mathrm{mL}$ streptomycin and $100 \mathrm{U} / \mathrm{mL}$ penicillin.

\subsection{MTT assay for cell viability}

Assessment of cell viability was made through a colorimetric assay, using MTT, as previously reported (Mosmann, 1983). The cells $\left(0.3 \times 10^{6}\right.$ cells/well) were cultured in 48 -well microplates, in a final volume of $600 \mu \mathrm{L}$, allowed to stabilize for $3 \mathrm{~h}$, and then incubated for $24 \mathrm{~h}$ with culture medium alone (control), or stimulated with $1 \mu \mathrm{g} / \mathrm{mL}$ LPS, or with $1 \mu \mathrm{g} / \mathrm{mL}$ LPS in the presence of varying concentrations $(0.64 \mu \mathrm{L} / \mathrm{mL}$ and $1.25 \mu \mathrm{L} / \mathrm{mL})$ of the essential oil diluted in culture medium. After removal of $170 \mu \mathrm{L}$ cell-free supernatants used to detect nitrite production, $43 \mu \mathrm{L}$ of MTT solution $(5 \mathrm{mg} / \mathrm{mL}$ in PBS) were added to each well. The microplates were further incubated at $37^{\circ} \mathrm{C}$ for $30 \mathrm{~min}$, in a humidified atmosphere of $95 \%$ air $/ 5 \% \mathrm{CO}_{2}$. Supernatants were then discarded and $300 \mu \mathrm{L}$ of acidified isopropanol $(0.04 \mathrm{~N} \mathrm{HCl}$ in isopropanol) were added to the cultures and mixed thoroughly to dissolve the dark 
Table 2

Antifungal activity (MIC and MLC) of Distichoselinum tenuifolium oil for yeasts, dermatophyte and Aspergillus strains.

\begin{tabular}{|c|c|c|c|c|c|c|c|c|}
\hline \multirow[t]{2}{*}{ Strains } & \multicolumn{2}{|l|}{ Essential oil } & \multicolumn{2}{|l|}{ Myrcene } & \multicolumn{2}{|c|}{ Fluconazole } & \multicolumn{2}{|c|}{ Amphotericin B } \\
\hline & $\mathrm{MIC}^{\mathrm{a}}$ & MLC & MIC & MLC & $\mathrm{MIC}^{\mathrm{b}}$ & MLC & MIC $^{b}$ & MLC $^{b}$ \\
\hline Candida albicans ATCC 10231 & 2.5 & 5 & $5.0-10.0$ & $>20.0$ & 1 & $>128$ & N.T. ${ }^{c}$ & N.T. \\
\hline Candida tropicalis ATCC 13803 & 5 & 5 & 20.0 & $>20.0$ & 4 & $>128$ & N.T. & N.T. \\
\hline Candida krusei $\mathrm{H} 9$ & 5 & 5 & 10.0 & 20.0 & 64 & $64-128$ & N.T. & N.T. \\
\hline Candida guillermondii MAT23 & 2.5 & $2.5-5$ & 2.5 & $>20.0$ & 8 & 8 & N.T. & N.T. \\
\hline Candida parapsilosis ATCC 90018 & 2.5 & $5-10$ & 2.5 & $>20.0$ & $<1$ & $<1$ & N.T. & N.T \\
\hline Cryptococcus neoformans CECT 1078 & $0.32-0.64$ & 0.64 & 0.64 & $1.25-0.64$ & 16 & 128 & N.T. & N.T. \\
\hline Trichophyton mentagrophytes FF7 & 0.64 & 1.25 & 5.0 & 5.0 & $16-32$ & $32-64$ & N.T. & N.T. \\
\hline Microsporum canis FF1 & 0.64 & 0.64 & $1.25-2.5$ & $1.25-2.5$ & 128 & 128 & N.T. & N.T. \\
\hline Trichophyton rubrum CECT 2794 & 0.64 & 1.25 & 2.5 & 2.5 & 16 & 64 & N.T. & N.T. \\
\hline Microsporum gypseum CECT 2905 & 1.25 & 1.25 & 5 & 5 & 128 & $>128$ & N.T & N.T. \\
\hline Epidermophyton floccosum FF9 & 0.64 & 0.64 & 1.25 & 2.5 & 16 & 16 & N.T. & N.T. \\
\hline Aspergillus niger ATCC16404 & 2.5 & $>20$ & $>20$ & $>20$ & N.T. & N.T & $1-2$ & 4 \\
\hline Aspergillus fumigatusATCC 46645 & 2.5 & $>20$ & $\geq 20.0$ & $>20.0$ & N.T. & N.T. & 2 & 4 \\
\hline Aspergillus flavus $\mathrm{F} 44$ & 20 & $\geq 20$ & $>20.0$ & $>20.0$ & N.T. & N.T. & 2 & 8 \\
\hline
\end{tabular}

Results were obtained from 3 independent experiments performed in duplicate.

a MIC and MLC were determined by a macrodilution method and expressed in $\mu \mathrm{L} / \mathrm{mL}(\mathrm{v} / \mathrm{v})$.

b MIC and MLC were determined by a macrodilution method and expressed in $\mu \mathrm{g} / \mathrm{mL}(\mathrm{w} / \mathrm{v})$.

c Not tested.

blue crystals of formazan. Formazan quantification was performed using an automatic plate reader (SLT, Austria) at $570 \mathrm{~nm}$, with a reference wavelength of $620 \mathrm{~nm}$.

\subsection{Nitric oxide measurement}

The production of NO was measured by the accumulation of nitrite in the culture supernatants, using a colorimetric reaction with the Griess reagent, as previously reported by us (Cruz et al., 2001 ). The cells were plated at $0.3 \times 10^{6}$ cells/well in 48 -well culture plates, and then incubated with culture medium (control), or stimulated with $1 \mu \mathrm{g} / \mathrm{ml}$ LPS or with $5 \mu \mathrm{g} / \mathrm{ml}$ LPS in the presence of the different samples, for $24 \mathrm{~h}$. Briefly, $170 \mu \mathrm{l}$ of culture supernatants were collected and diluted with equal volumes of the Griess reagent $[0.1 \%(\mathrm{w} / \mathrm{v}) \mathrm{N}-(1$-naphthyl)ethylenediamine dihydrochloride and $1 \%(\mathrm{w} / \mathrm{v})$ sulphanilamide containing $5 \%(\mathrm{w} / \mathrm{v}) \mathrm{H}_{3} \mathrm{PO}_{4}$ ], during $20 \mathrm{~min}$, in the dark. The absorbance at $550 \mathrm{~nm}$ was measured in an automated plate reader (SLT, Austria). Nitrite concentration was determined from a sodium nitrite standard curve.

\subsection{Data analysis}

All the experiments were performed in duplicate. Results are presented as mean \pm standard error (SE) of the indicated number of experiments, and the means were statistically compared using the one-way ANOVA test, with a Dunnett's post-test. The significance level was ${ }^{*} p<0.05,{ }^{* *} p<0.01,{ }^{* * *} p<0.001$.

\section{Results}

\subsection{Essential oil analysis}

Essential oils were extracted with yields of $1 \%$ for flowering umbels and ranging from $2.0 \%$ to.2.6\% for ripe umbels $(\mathrm{v} / \mathrm{w})$. The oils were analyzed by GC and GC-MS and the qualitative and quantitative compositions are presented in Table 1, where compounds are listed in order of their elution on a polydimethylsiloxane column. In general, the composition of the oils obtained from two different locations (Moncarapacho and Burgau) and from two different stage of plant development is similar. The samples are predominantly composed of monoterpene hydrocarbons (86.2-93.1\%), being myrcene the main compound (47.7-84.6\%). Myrcene showed the higher concentration in the oils obtained from ripe umbels. Some qualitative differences were observed particularly in the amounts of limonene, which attained an important percentage in the oils obtained from Burgau (13.6-19.9\%). Oxygenated monoterpenes and sesquiterpenes attained only $0.9-5.1 \%$ and $0.6-5.2 \%$, respectively.

\subsection{Antifungal activity}

Evaluation of MIC and MLC of the oil showed a variability of inhibition among all the fungi tested (Table 2). Cryptococcus neoformans and dermatophyte strains showed more sensibility to this oil when compared with Candida and Aspergillus ssp. For these strains MIC and MLC values ranging from $0.32 \mu \mathrm{L} / \mathrm{mL}$ to $1.25 \mu \mathrm{L} / \mathrm{mL}$ (Table 2). We also evaluated the fungicidal activity of myrcene, the major compound of the oil, and our results demonstrated that the oil had higher fungicidal activity than myrcene alone.

\subsection{Effect of the essential oils on macrophages viability}

To evaluate the possible cytotoxic activity of the oil, the MTT assay was used. After $24 \mathrm{~h}$ of cells exposure, neither LPS nor the

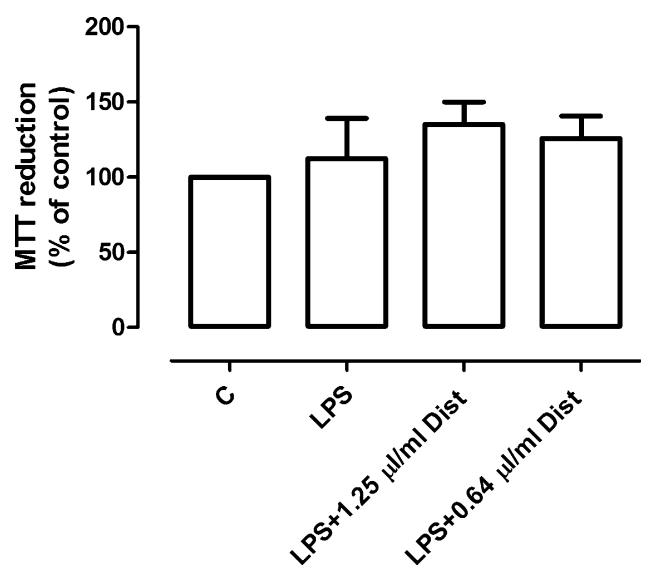

Fig. 1. Effect of essential oils extracted from Distichoselinum tenuifolium on macrophages viability (MTT assay). The macrophages $\left(0.3 \times 10^{6}\right.$ cells) were maintained in culture medium (control), or were incubated with $1 \mu \mathrm{g} / \mathrm{mL}$ LPS, or with LPS in the presence of the two concentrations of the essential oil $(0.64 \mu \mathrm{L} / \mathrm{mL}$ and $1.25 \mu \mathrm{L} / \mathrm{mL}$ ), for $24 \mathrm{~h}$. The MTT assay was performed as described in Section 2 . Results are expressed as a percentage of MTT reduction by control cells maintained in culture medium. Each value represents the mean \pm SE from 3 experiments, performed in duplicate. 


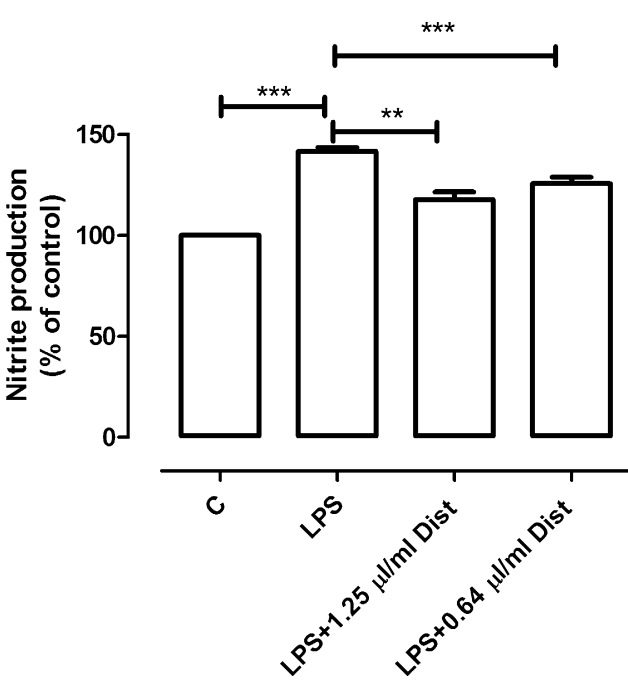

Fig. 2. Effect of of essential oils extracted from Distichoselinum tenuifolium on NO production in macrophages. The macrophages $\left(0.3 \times 10^{6}\right.$ cells $)$ were maintained in culture medium (control), or were incubated with $1 \mu \mathrm{g} / \mathrm{mL}$ LPS, or with LPS in the presence of the two concentrations of the essential oil $(0.64 \mu \mathrm{L} / \mathrm{ml}$ and $1.25 \mu \mathrm{L} / \mathrm{mL})$, for $24 \mathrm{~h}$. Nitrite levels in the culture supernatants were evaluated by the Griess reaction as described in Section 2. Results are expressed as a percentage of nitrite production by control cells maintained in culture medium. Each value represents the mean \pm SE from 3 experiments, performed in duplicate $\left({ }^{* *} p<0.01 ;{ }^{* * *} p<0.001\right)$.

oil had significant effect on cell viability for all the concentrations tested $(0.64 \mu \mathrm{L} / \mathrm{mL}$ and $1.25 \mu \mathrm{L} / \mathrm{mL})$. As shown in Fig. 1 , the two concentrations of the oil slightly increased the reduction of MTT by macrophages; however this effect was not statistically significant, when compared to cells incubated with LPS alone. A cell-free control was performed in order to exclude non-specific effects of the oils on MTT.

\subsection{Effect of the essential oils on nitric oxide production induced by LPS}

Incubation of macrophages with LPS, during $24 \mathrm{~h}$, resulted in a significant increase in nitrite production, reflecting an increase in NO production, namely to $141.6 \pm 1.9 \%$ above control $(p<0.001)$. After macrophages stimulation with LPS in the presence of the two concentration of the oil, namely $0.64 \mu \mathrm{L} / \mathrm{mL}$ and $1.25 \mu \mathrm{L} / \mathrm{mL}$, nitrite production induced by LPS was reduced to $117.7 \pm 3.7 \%(p<0.01)$ and $125.6 \pm 3.2 \%(p<0.001)$ of the control, respectively (Fig. 2$)$.

\section{Discussion and conclusions}

In this paper it was demonstrated that Distichoselinum tenuifolium essential oils had fungicidal activity and significantly inhibited nitric oxide production induced by LPS in macrophages, at concentrations that did not affect mammalian cells viability.

The oils of Distichoselinum tenuifolium were characterized by high amounts of myrcene $(>48 \%)$ and no significant variations were observed in the chemical compositions during ontogenesis.

Distichoselinum tenuifolium (= Elaeoselinum tenuifolium) is the only species of the genus. Highs amounts of myrcene were not observed in the oils of Elaeoselinum species, a genus taxonomically related. In the majority of the Elaeoselinum species $\alpha$-pinene was the main component of the oils (Ortega et al., 1986; Pala-Paul et al., 2001). These results support the separation of this taxon from the genus Elaeoselinum, supported by taxonomic characters and also by phytochemical studies.

Apiaceae essential oils are known to possess antimicrobial activity against a wide spectrum of microorganisms (Ekiert, 2000; Di Pasqua et al., 2005; Kosalec et al., 2005; Ozcan et al., 2006; Demirci et al., 2007; Tavares et al., 2008; Oroojalian et al., 2010). Accordingly, our results demonstrated that Distichoselinum tenuifolium oil showed effective antifungal activity against Cryptococcus neoformans and dermatophyte strains, with MIC and MLC values ranging from $0.32 \mu \mathrm{L} / \mathrm{mL}$ to $1.25 \mu \mathrm{L} / \mathrm{mL}$. In most cases the MIC was equivalent to the MLC, indicating a fungicidal effect of the oil. These results highlight the potential utilization of Distichoselinum tenuifolium oil in dermatomycoses, which are common infections caused by filamentous fungi and by some yeasts that can be severe in immunocompromised patients. The higher susceptibility of dermatophytes has also been reported for other essential oils (Figueiredo et al., 2008; Zuzarte et al., 2009; Pinto et al., 2009). The superior activity of Distichoselinum tenuifolium oil, compared to that of its main compound assayed individually, myrcene, is presumably due to the synergistic effect among the different compounds present in the oil.

Although the potential use of Apiaceae essential oils as antimicrobial has been described previously, studies concerning its anti-inflammatory properties are scarce. The work of Tabanca et al. (2007) addressed the role of essential oils from Pimpinella species in inflammation. The authors verified that Pimpinella essential oils inhibited the transcription nuclear factor NF-kappaB, which is strongly activated in inflammatory conditions. In addition, the anti-inflammatory activity of $\beta$-myrcene was previously reported in a mouse model of pleurisy (Souza et al., 2003). In this work we also provided evidences, for the first time, of the anti-inflammatory properties of the Distichoselinum tenuifolium oil. Indeed, and for the two concentrations tested, the oil decreased the nitric oxide production triggered by LPS without affecting cells viability. Accordingly, no cytotoxicity was previously observed for myrcene, the main compound of Distichoselinum tenuifolium oil, in human lymphocytes and hamster lung fibroblasts (Kauderer et al., 1991).

Overall the present findings provide consistent evidence that Distichoselinum tenuifolium oil has anti-inflammatory and antifungal activities. This study also justifies and reinforces the use of this plant on traditional medicine in the Iberian Peninsula, mainly on the treatment of contact dermatitis, characterized by a strong inflammatory component, and on skin infections. Additional studies are necessary to explore in more depth its potential beneficial use in inflammatory diseases and infections caused by fungi.

\section{Acknowledgements}

Our thanks to the following institutions for supporting this work: Center of Pharmaceutical Studies of the University of Coimbra (POCI2010FEDER) and EDP/Electricity Portuguese Foundation. To the Institute of Interdisciplinary Research of the University of Coimbra our thanks for the Ph-D grant - III/05/2007 - of Ana Cristina Tavares.

\section{References}

Adams, R.P., 2004. Identification of Essential Oil Components by Gas Chromatography/Mass Spectroscopy. Allured Publishing Corporation Stream, IL, USA. Castroviejo, S., 2003. Flora Ibérica, vol X. Real Jardín Botánico, CSIC.

1997. European Pharmacopeia, 3rd ed. Council of Europe, Strasbourg.

2008a. Reference Method for Broth Dilution Antifungal Susceptibility Testing of Yeasts. Approved standard document M27-A3. Clinical and Laboratory Standards Institute, Wayne.

2008b. Reference method for broth dilution antifungal susceptibility testing of yeasts; third informational supplement M27-S3. Clinical and Laboratory Standards Institute (CLSI), Wayne.

2008c. Reference Method for Broth Dilution Antifungal Susceptibility Testing of Filamentous Fungi. Approved standard document M38-A. Clinical and Laboratory Standards Institute, Wayne.

Cruz, M.T., Duarte, C.B., Gonçalo, M., Figueiredo, A., Carvalho, A.P., Lopes, M.C. 2001. Granulocyte-macrophage colony-stimulating factor activates the transcription of nuclear factor kappa B and induces the expression of nitric oxide synthase in a skin dendritic cell line. Immunology and Cell Biology 79, 590-596. 
Demirci, B., Koşar, M., Demirci, F., Dinç, M., Başer, K.H.C., 2007. Antimicrobial and antioxidant activities of the essential oil of Chaerophyllum libanoticum Boiss. et Kotschy. Food Chemistry 105, 1512-1517.

Di Pasqua, R., De Feo, F., Villani, F., Mauriello, G., 2005. In vitro antimicrobial activity of essential oils from Mediterranean Apiaceae. Verbenaceae and Lamiaceae against food borne pathogens and spoilage bacteria. Annals of Microbiology 55 $139-143$.

Edris, A.E., 2007. Pharmaceutical and therapeutic Potentials of essential oils and their individual volatile constituents: a review. Phytotherapy Research 21, 308-323.

Ekiert, H., 2000. Medicinal plant biotechnology: the Apiaceae family as the example of rapid development. Pharmazie 55, 561-567.

Figueiredo, A.C., Barroso, J., Pedro, L., Salgueiro, L., Miguel, M.G., Faleiro, M.L., 2008 Portuguese Thymbra and Thymus species volatiles: chemical composition and biological activities. Current Pharmaceutical Design 14, 3120-3140.

Hofseth, L.J., 2008. Nitric oxide as a target of complementary and alternative medicines to prevent and treat inflammation and cancer. Cancer Letters 268 10-30.

Joulain, D., Koning, W.A., 1998. The Atlas of Spectral Data of Sesquiterpene Hydrocarbon. B. Verlag, Hamburg.

Kauderer, B., Zamith, H., Paumgartten, F.J., Speit, G., 1991. Evaluation of the mutagenicity of beta-myrcene in mammalian cells in vitro. Environmental and Molecular Mutagenesis 18, 28-34.

Khoshbakht, K., Hammer, K., Pistrick, K., 2007. Eryngium caucasicum Trautv. cultivated as a vegetable in the Elburz Mountains (Northern Iran). Genetic Resources Crop Evolution 54, 445-448.

Kosalec, I., Pepeljnjak, S., Kustrak, D., 2005. Antifungal activity of fluid extract and essential oil from anise fruits (Pimpinella anisum L., Apiaceae). Acta Pharmaceutica 55, 377-385.

Küpeli, E., Tosun, A., Yesilada, E., 2006. Anti-inflammatory and antinociceptive activities of Seseli L. species (Apiaceae) growing in Turkey. Journal of Ethnopharmacology 104, 310-314.

Martin, F.G., Silvestre, S., 1983. Distichoselinum Garcia Martin \& Silvestre género nuevo de Umbelliferae. Lagascalia 12, 99-107.

Morillas-Sánchez, L., Fernández-López, C., 2006. Plantas útiles en el valle del Guadiana Menor (Jaén, Sur de la Península Ibérica). Blancoana 22, 65-103.
Mosmann, T., 1983. Rapid colorimetric assay for cellular growth and survival: application to proliferation and cytotoxicity assays. Journal of Immunological Methods 65, 55-63.

Oroojalian, F., Kasra-Kermanshahi, R., Azizi, M., Bassami, M.R., 2010. Phytochemical composition of the essential oils from three Apiaceae species and their antibacterial effects on food-borne pathogens. Food Chemistry 120, 765-770.

Ortega, H.-A., Carretero, T., Bermejo, M.E., Pardo, P., 1986. Aceites esenciales en Umbelíferas. Estudio del aceite esencial de Elaeoselinum asclepium subsp. asclepium. Anales Jardim Bot Madrid 43, 121-124.

Ozcan, M.M., Chalchat, J.-C., Arslan, D., Ates, A., Unver, A., 2006. Comparative Essential Oil Composition and Antifungal Effect of Bitter Fennel (Foeniculum vulgare ssp.piperitum) Fruit Oils Obtained During Different Vegetation. Journal of Medicinal Food 9, 552-561.

Pala-Paul, J., Perez-Alonso, M.J., Velasco-Negueruela, A., 2001. Contribution to the knowledge of the oil of Elaeoselinum gummiferum (Desf.) Tutin. Journal of Essential Oils Research 13, 362-363.

Pinto, E., Vale-da-Silva, Cavaleiro, C., Salgueiro, L., 2009. Antifungal activity of the clove essential oil from Syzygium aromaticum on Candida, Aspergillus and dermatophyte species. Journal of Medical Microbiology 58, 1454-1462.

Ronda, A.O., Caballero, D., Serrano, F.M., Tomizo, F.M., Campaña, M.A., Moral, R., Padilla, R., 1998. Etnobotânica del Subbético Cordobés. Recupera tus traditiones. Taller de Etnobotánica, Carcabuey.

Souza, M.C., Siani, A.C., Ramos, M.F., Menezes-de-Lima, O.J., Henriques, M.G., 2003. Evaluation of anti-inflammatory activity of essential oils from two Asteraceae species. Pharmazie 58, 582-586.

Tabanca, N., Ma, G., Pasco, D.S., Bedir, E., Kirimer, N., Baser, K.H., Khan, I.A., Khan, S.I., 2007. Effect of essential oils and isolated compounds from Pimpinella species on NF-kappaB: a target for antiinflammatory therapy. Phytotherapy Research 21, 741-745.

Tavares, A.C., Gonçalves, M.J., Cavaleiro, C., Cruz, M.T., Lopes, M.C., Canhoto, J.M., Salgueiro, L., 2008. Essential oil of Daucus carota subsp. halophilus: chemical composition, antifungal activity and citotoxicity. Journal of Ethnopharmacology $119,129-134$

Zuzarte, M, Gonçalves, M.J., Cavaleiro, C., Dinis, A., Canhoto, J., Salgueiro, L., 2009. Chemical composition and antifungal activity of the essential oils of Lavandula pedunculata. Chemistry and Biodiversity 6, 1283-1292. 